\title{
PABRIK GASIFIKASI BERBASIS EDUKASI DAN REKREASI AIR SEBAGAI SOLUSI PENCEMARAN SAMPAH PLASTIK SUNGAI CITARUM KABUPATEN BANDUNG
}

\author{
Kevin Joshua Adiyanto Hutagaol ${ }^{1}$, Martin Halim $^{2)}$ \\ 1)Program Studi S1 Arsitektur, Fakultas Teknik, Universitas Tarumanagara, kvnjsh5@gmail.com \\ 2) Program Studi S1 Arsitektur, Fakultas Teknik, Universitas Tarumanagara, martinhalim90@gmail.com
}

Masuk: 03-07-2021, revisi: 15-08-2021, diterima untuk diterbitkan: 23-10-2021

\begin{abstract}
Abstrak
Eksistensi sampah plastik dapat diibaratkan seperti kanker ganas yang semakin lama akan menginvasi dan menghancurkan seluruh kehidupan di bumi. Indonesia sendiri merupakan negara penghasil sampah plastik terbesar nomor dua di dunia. Upaya Indonesia dalam menangani masalah tersebut masih belum optimal. Kombinasi antara kurangnya kesadaran masyarakat dan manajemen sampah menjadikan sampah plastik sebagai permasalahan utama yang mengancam keseluruhan ekosistem Indonesia. Sungai Citarum sebagai sungai purba yang menjadi sumber kebutuhan orang-orang selama ribuan tahun pun mulai lumpuh dan justru memberikan dampak buruk bagi ekosistem lainnya. Menciptakan peraturan ataupun sekedar mengumpulkan sampah bukan menjadi tugas seorang arsitek, namun dengan kemampuan desain yang kita miliki, kita dapat membangun sebuah wadah sebagai tempat pengolahan, edukasi, sosialisasi maupun rekreasi. Proyek dengan nama Lahir Alir Hilir sebagai Pabrik Gasifikasi dan Rekreasi hadir untuk memenuhi kebutuhan-kebutuhan tersebut sebagai wadah. Dengan memenuhi enam parameter ekologi dan juga pendekatan dengan metode kontekstual menjadikan proyek Lahir Alir Hilir sebagai contoh atau salah satu solusi bagi penyelesaian permasalahan utama sampah plastik di Indonesia.
\end{abstract}

Kata Kunci: Pabrik Gasifikasi; Pengolahan Sampah; Sampah plastik

\begin{abstract}
The existence of plastic waste can be equated as a malignant cancer that's more and more invading and destroy the life that is on earth. Indonesia itself is the second largest producer of plastic waste in the world. Indonesia's efforts in dealing with this matter are still not optimal. Combination between people lack of awareness and lack of waste management create plastic issue as a main problem that threatened the entire country's ecosystem. Citarum river as an ancient river that has been a source for the people for thousands of years has begun to collapse and even makes an impact on other ecosystems. Rule - making or simply waste collecting is not part of architects job, but with the design skills that we have, we can build a place for processing, educating, socializing or even recreation. The project with the name Lahir Alir Hilir as Gasification Plant and Recreational Space is here to meet these needs as a place. By fulfilling the six ecological parameters as well as using contextual method as an approach, Lahir Alir Hilir project can become an example or solution in solving plastic waste issue in Indonesia.
\end{abstract}

Keywords: Gasification plant; Waste management; Plastic waste 


\section{PENDAHULUAN}

\section{Latar Belakang}

Sungai merupakan ekosistem dalam kesatuan ekologi yang menjadi kebutuhan utama selama ribuan bahkan jutaan tahun. Sungai turun temurun memberikan peranan penting terhadap kelangsungan makhluk hidup. Pada tahun 2010 saja Indonesia tercatat sebagai penyumbang sampah plastik nomor dua terbesar setelah China. Lalu pada tahun 2013 titik awal pencemaran sungai Citarum dimulai, dimana berdasarkan pernyataan Blacksmith Institute dan Green Cross Switzerland sungai Citarum dinobatkan sebagai salah satu dari sepuluh sungai terkotor di dunia. Sindonews.com (2013) menyebutkan bahwa pencemaran berasal dari kotoran ternak, industri bahkan limbah domestik. Data tersebut didukung oleh penelusuran oleh Yayasan Kehati dimana 60\% komposisi limbah pencemaran sungai Citarum merupakan limbah domestik, 30\% merupakan industri dan 10\% sisanya merupakan limbah ternak atau tani. Dilanjutkan dengan data sampah plastik sebagai sampah kedua terbanyak setelah sampah organik yakni sebesar $18 \%$. Memang jumlah yang kecil jika dinyatakan dalam bentuk persentase, namun kenyataan yang dapat kita lihat secara langsung sampah plastik sungai Citarum sudah sangat memprihatinkan dan terus menumpuk. Penumpukan sampah plastik tersebut pada akhirnya menyebabkan permasalahan lain seperti erosi sungai dan pedangkalan dasar sungai. Hal tersebut dapat kita temui setiap tahunnya di Kabupaten Bandung. Kecamatan Baleendah, Kecamatan Bojongsoang dan Kecamatan Dayeuhkolot menjadi tiga kecamatan yang namanya paling sering terpampang pada headline berita dikarenakan bencana banjir yang terus melanda kecamatan tersebut sampai pada tahun 2021 ini. Namun, dapat ditelusuri kembali, permasalahan luapan dan pencemaran sampah plastik diawali oleh dua hal yakni kurangnya kesadaran masyarakat terhadap pentingnya pelestarian sungai dan lemahnya sistem pengolahan sampah yang ada. Disebutkan pada wawancara oleh DW Indonesia (2020) bahwa terkadang masyarakat tidak memiliki saluran untuk membuang sampah sehingga mereka merasa akan lebih mudah untuk membuang sampah langsung ke sungai. Pada tahun 2018 isu tersebut sudah diangkat mengenai penyebaran titik pengelolaan yang tidak merata dan radius yang sangat kurang, dilanjutkan ribuan ton sampah tidak terangkut pada tahun 2019. Jika dilihat secara langsung melalui google maps, dari tujuh tempat pengolahan sampah yang efektif hanya ada tiga titik saja dalam radius $112 \mathrm{~km}^{2}$, sementara empat lainnya hanya berupa tempat penampungan sampah ataupun bank sampah yang akan dibawa ke tempat pembuangan akhir. Padahal pada tahun 2021 mediaindonesia.com kembali menyebutkan bahwa TPA Sarimukti di Kecamatan Cipatat sudah melebihi kapasitas atau overload. Dari datadata yang telah dipaparkan diatas membuktikan kedaruratan sampah plastik sungai Citarum yang sudah mencemaskan. Ditambah lagi dengan pencemaran sampah plastik di laut yang terbawa langsung oleh arus sungai semakin memberikan gambaran bahwa pencemaran ekosistem sungai menjadi hal krusial.

\section{Rumusan Masalah}

Studi desain yang akan diisukan pada proyek ini bukanlah hanya mengenai desain proyek sebagai wadah tempat pengolahan sampah dan rekreasi, namun juga penyusunan sistem pengolahan sampah dimulai dari titik awal pengumpulan sampah plastik sampai produk akhir yang diolah. Lebih lanjut lagi, yang menjadi isu adalah bagaimana penataan desain akhir aan terbentuk dikarenakan bentukan pabrik yang cenderung lebih baru atau tidak seperti biasanya dengan aktifitas campuran seperti rekreasi juga edukasi yang terbuka untuk umum. 


\section{Tujuan}

Berdasarkan rumusan masalah yang ada studi perancangan tersebut ingin memberikan solusi berupa penyediaan wadah dan program arsitektural yang relevan. Program yang pertama adalah penyediaan tempat daur ulang sampah plastik sebagai bagian dari penyelesaian masalah sampah plastik yang menutupi dan mengendap di sungai Citarum. Penyediaan tempat rekreasi sungai untuk meningkatkan kesadaran masyarakat akan pentingnya melestarikan sungai Citarum. Lalu menyediakan tempat edukasi terhadap pengolahan sampah. Dengan kehadiran proyek tersebut diharapkan proyek tersebut dapat menyelesaikan permasalahan pencemaran sampah plastik di Sungai Citarum dan juga dapat meningkatkan kesadaran dan pengetahuan masyarakat terhadap pentingnya pelestarian sungai Citarum.

\section{KAJIAN LITERATUR}

\section{Cradle to Cradle}

Mcdonough dan Braungart (2002) menjelaskan di dalam tulisan mereka yang berjudul "Cradle to Cradle" bahwa pemahaman manusia terhadap reduce, reuse and recycle selama ini dapat dikatakan masih kurang tepat dalam benar-benar mewujudkan keseimbangan lingkungan. Meskipun demikian Mcdonough dan Braungart menginisiasikan gerakan yang mereka nilai lebih efektif dalam menerapkan lingkungan yang aman dan tentram, yakni "eco-effectiveness".

\section{Seaspiracy}

Film dokumenter 2021 arahan Ali Tabrizi mengangkat mengenai permasalahan utama sampah plastik dan pengaruhnya terhadap keseimbangan ekosistem laut. Film ini menyorot hal buruk dari berbagai sisi mengani overfishing dan juga pencemaran sampah plastik. Tidak hanya kedua hal tersebut akan merusak rantai kehidupan bawah laut dari segi populasi yang sulit terkontrol namun juga akan menghilangkan ciri khas bawah laut yaitu terumbu karang, dengan hilangnya rumah bagi para ikan otomatis akan semakin merusak ekosistem yang ada dikarenakan akan semakin hilangnya beberapa spesies ikan dan kembali memberikan ketidakseimbangan bagi populasi ikan lainnya.

\section{Biomass sources in Parkstad - Research on conditions as a renewable energy}

Tulisan oleh Yixin Lyu sebagai keperluan master thesis pada Faculty of Architecture \& the Built Environment, Delft University of Technology menjadi salah satu kajian dalam melakukan riset proyek tugas akhir. Proyek beliau berupa pembangkit listrik biomass dengan konsep membaur dengan kehidupan keseharian masyarakat disekitar, sehingga dilakukan penambahan rekreasi pada rancangan.

\section{Gasification of Non-Recycled Plastics From Municipal Solid Waste In the United States}

Dibuat oleh Gershman, Brickner \& Bratton, Inc. sebagai ringkasan atau dasar singkat pembuatan tempat pengolahan sampah padat di Amerika. Dalam tulisan ini dijelaskan beberapa hal umum yang perlu diketahui untuk memahami apa itu pabrik gasifikasi yang menjadi program proyek ini. Mulai dari contoh nyata, pendekatan dalam pembangunan pabrik di wilayah pembangunan dan juga skema prosesnya. Proses gasifikasi yang diikutsertakan berdasarkan proyek nyatanya dituliskan dalam bentuk yang jauh lebih mudah dipahami.

\section{Supplemental Report: The Evolution of Mixed Waste Processing FacilitiesTechnology and Equipment Guide}


Buku panduan yang dikeluarkan oleh Gershman, Brickner \& Bratton, Inc. untuk menjelaskan kebutuhan mesin-mesin pengolahan, gambaran juga cara kerja mesin pengolahan.

\section{Waste Bank as Community-based Environmental Governance: A Lesson Learned from Surabaya}

Jurnal karya Dyah Retno Wijayanti dan Sri Suryani mengenai kesuksesan penerapan bank sampah di Surabaya. Bank Sampah sudah mulai mendapatkan reputasi yang baik di Indonesia, dikarenakan melalui penjualan bank sampah pun orang-orang bisa mendapatkan pemasukan yang cukup. Organisasi sampah melalui Bank Sampah juga dapat diatur dengan lebih baik dikarenakan orang-orang akan lebih mengapresiasi sampah itu sendiri.

\section{Gratitude to Nature}

Riset oleh Kim-Pong Tam dari The Hong Kong University of Science and Technology tentang pembedahan kembali konsep, pola dan aktifitas yang dapat dikatakan pro-environmental behavior menjadi landasan dalam merancang konsep rekreasi nantinya. Dengan mengedepankan prinsip edukatif dan rekreatif melalui pengalaman, keterhubungan dan derajat dengan alam untuk mendorong kesadaran akan kebersihan sungai dari sampah plastik.

\section{METODE}

Metode perancangan yang digunakan dalam proyek ini adalah:

\section{a. Studi Literatur}

Studi literatur yang diambil dari Mcdonough \& Braungart (2018) dan Seaspiracy (2021) menjadi landasan pemahaman mengenai 'melampaui' ekologi dan dasar pengangkatan isu 'sampah plastik'. Lalu terdapat pula lima studi literatur tambahan sebagai landasan perancangan tempat pengolahan sampah berbasih rekreasi dan edukasi.

\section{b. Studi Preseden}

Karya arsitektur yang dipakai sebagai referensi proyek tugas akhir adalah Waste to Energy Plant oleh Schmidt Hammer Lassen dan Gottlieb Paludan, Bozen Waste to Energy Plant dan Enerkem Alberta Biofuels.

\section{c. Kontekstual}

Proyek tugas akhir di desain menggunakan metode desain kontekstual menurut Brent C. Brolin (1980) yang mana arsitektur kontekstual terbagi atas dua kelompok, kontras dan harmoni. Dimana metode yang diambil yakni kontekstual kontras dan melalui metode ini perancangan menghasilkan bangunan yang berbeda dengan yang sudah ada namun masih mengikuti dan menyesuaikan secara langsung dengan kondisi tapak setempat. Adapun proses desain yang dipakai terdiri dari analisis tapak, implementasi desain dan zonasi detail tapak. 1). Analisis Tapak, proses utama yang dipakai dalam menentukan posisi strategis bangunan dan titik program yang akan dibentuk nantinya. 2). Implementasi Desain, alam mencapai bentukan yang selaras dengan lingkungan, dilakukan implementasi desain berdasarkan tipologi area Kabupaten Bandung dan simulasi pembentukan pola-pola sampah. 3). Zonasi Detail Tapak, melalui penggambaran skema sirkulasi bangunan mulai dari pintu masuk sampai pada aktifitas di dalamnya.

\section{DISKUSI DAN HASIL}

\section{Sungai Citarum, Kabupaten Bandung}

Lokasi terpilih berada di Kecamatan Margaasih, Kabupaten Bandung. Sebelumnya pemilihan Kabupaten Bandung sendiri didasari oleh permasalahan sampah plastik yang menjadi salah 
satu bentuk pencemaran sungai Citarum dan juga merupakan penyulut permasalahan luapan sungai Citarum yang mengakibatkan banjir (cleancurrentscoalition.org, 2021). Banjir yang sering terjadi di Kabupaten Bandung terus menjadi domino bagi permasalahan ekologi lainnya seperti pencemaran sawah dan juga kerusakan tempat tinggal manusia maupun hewan dan tentunya ekonomi yang dirugikan untuk memperbaiki semua kerusakan. Tidak hanya itu, sampah plastik juga sudah lama menjadi ancaman bagi ekosistem laut. Ketika kita berbicara tentang laut mungkin dengan mudah kita akan menyimpulkan bahwa penyebaran sampah tersebut berasal dari pariwisata dipesisir pantai. Namun masih ada sumber yang memberikan pengaruh lebih besar yaitu Sungai. Sungai Citarum terbentang dari mata air aslinya situ Cisanti sampai dengan pesisir Utara lautan Jawa. Menurut forbes.com dan kajian yang bersumber dari film dokumenter Seaspiracy membahas mengenai Great Pacific Garbage Patch yang merupakan genangan sampai plastik dengan ukuran 1,6 juta $\mathrm{km}^{2}$. Berdasarkan analisis gabungan dari kedua sumber tersebut, sebesar $10 \%$ tumpukan sampah plastik di pulau buatan tersebut merupakan jarring-jaring penangkap ikan, sementara $90 \%$ lainnya adalah sampah plastik yang berasal dari daratan. Data yang serupa juga menunjukkan bagaimana sebenarnya sampah plastik daratan secara tidak langsung menjadi ancaman yang sangat besar bagi ekosistem lautan melalui mediasi sungai. Sebanyak $9 \%$ dari 6.800 .000 ton sampah plastik bocor ke laut, danau dan sungai sementara $61 \%$ atau 4.200 .000 tidak terdata, berpotensi ikut menjadi pencemaran ekosistem sungai atau laut maupun polusi lainnya.
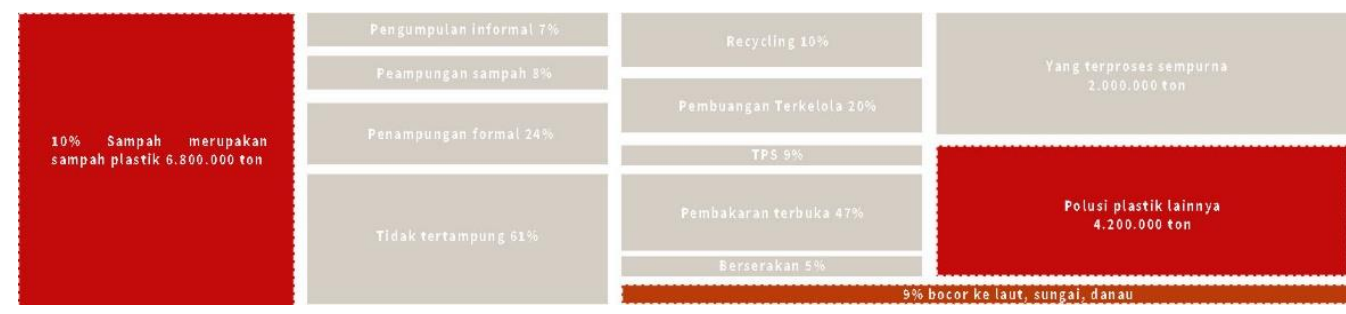

Gambar 1. Perjalanan Sampah Plastik

Sumber: Penulis, 2021

Kebocoran tersebut terjadi salah satunya dikarenakan kurangnya tempat pengolahan sampah yang memadai dalam segi fasilitas maupun luasan ruang. Penyebab lainnya seperti yang kita ketahui merupakan kesadaran masyarakat yang masih kurang. Kedua hal tersebut bisa kita temui di sungai Citarum, sungai yang dikenal sebagai sungai salah satu sungai terkotor didunia dan permasalahan ini tidak asing lagi bagi Kabupaten Bandung. Kebanyakan dari tempat manajemen sampah hanyalah berupa penampungan yang akhirnya terus melakukan pembakaran sampah sebagai "upaya" pengurangan jumlah sampah, namun faktanya hanya akan menjadi polusi baru bagi udara disekitar area penampungan. Kesadaran masyarakat yang masih kurang dapat ditemui dengan adanya jejak-jejak sampah di sepanjang aliran sungai. Tapak yang cocok dengan mengikuti tujuan awal proyek tersebut dibangun adalah pinggiran sungai dan dari sekian banyak alternatif yang ada Jalan Terusan Nanjung Kecamatan Margaasih dinilai sesuai dengan kebutuhan proyek (zonasi yang sesuai, akses yang cukup mudah, terhindar dari banjir, jauh dari kepadatan). 

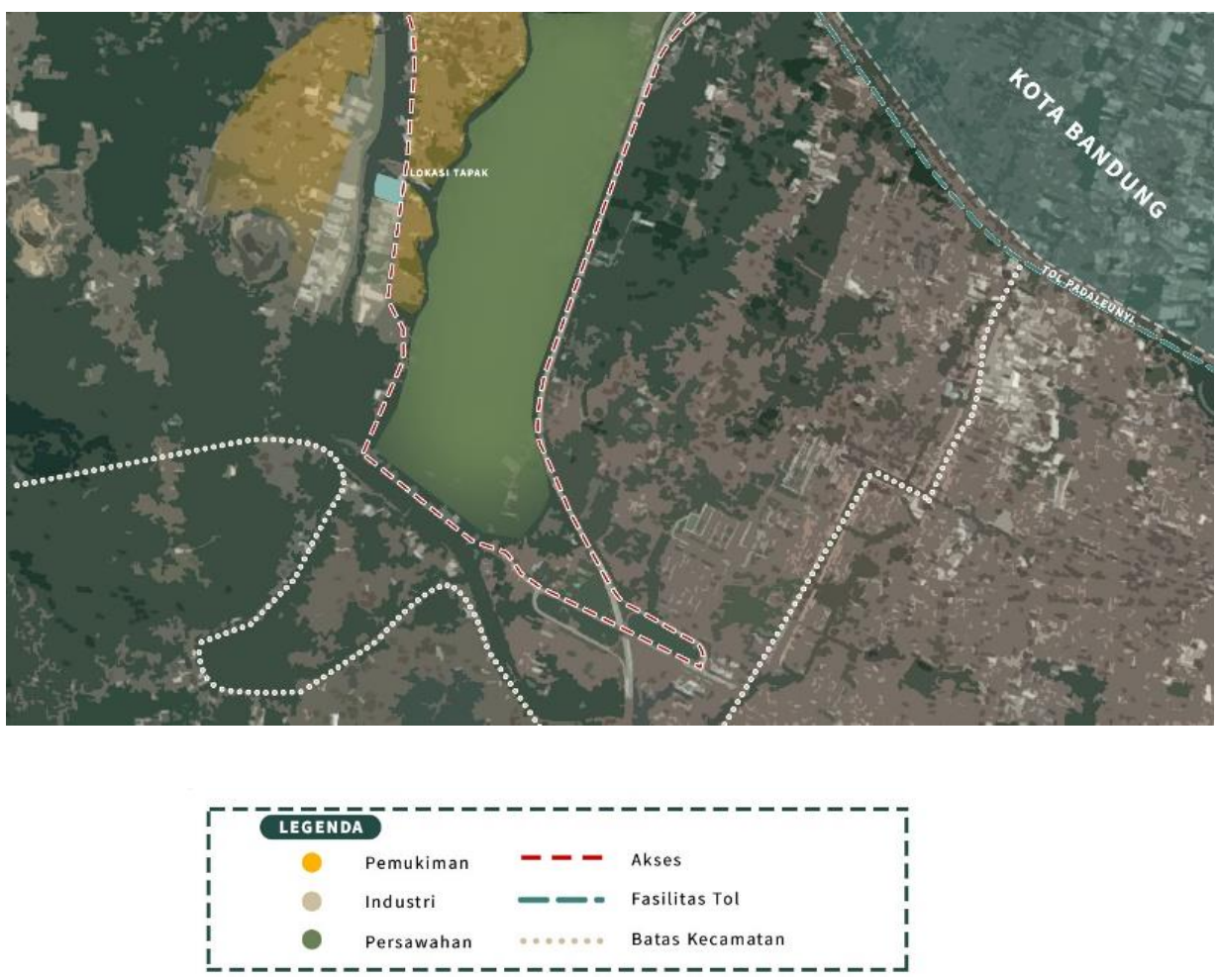

Gambar 2. Tapak Terpilih

Sumber: Penulis, 2021

\section{Programatik}

Dalam mendesain, proses merupakan basis bagi desain yang kreatif. Terdapat enam parameter dalam menyanggah topik utama " 'Melampaui' Ekologi" yaitu konteks, energi, adaptasi, resiliensi, teknologi dan keberlangsungan. Dalam parameter tersebut setidaknya tiga diantaranya terkait dengan isu sampah plastik yang menjadi fokus utama proyek ini dibangun dan dapat menjadi petunjuk utama dalam membangun desain yang menjawab persoalan. 1). Energi, mendesain bangunan dengan aspek ramah lingkungan dan penerapan zero emission goal 2). Teknologi, dalam menyelesaikan persoalan yang berkaitan dengan isu 3). Keberlangsungan, desain yang tahan lama bahkan akan terus relevan dalam perkembangan jaman. Parameter lainnya akan tetap menjadi tolak ukur yang penting, namun lebih ke dalam penyesuaian dengan proses arsitektur yang dibuat. Tiga parameter ini dan teori Cradle to Cradle menjadi landasan bagi proses desain proyek ini. Sebelumnya yang harus dilakukan adalah menentukan program. Pemilihan program proyek ini dilakukan melalui penyusunan skema permasalahan berdasarkan data lapangan Kabupaten Bandung terlebih Kecamatan Margaasih berupa 1). Fakta Lapangan, yang adalah pembuangan sampah sembarangan yang mengakibatkan pencemaran sungai citarum 2). Masalah, masalah lain yang disebabkan oleh fakta lapangan 3). Hipotesis, respon sementara terhadap permasalahan yang ada 4). Solusi, bentuk nyata dari hipotesis sementara dalam hal ini edukasi, menghadirkan rekreasi sungai dan menghadirkan tempat pengolahan sampah sehingga menghasilkan empat program utama yakni ruang publik, daur ulang, rekreasi dan edukasi. 


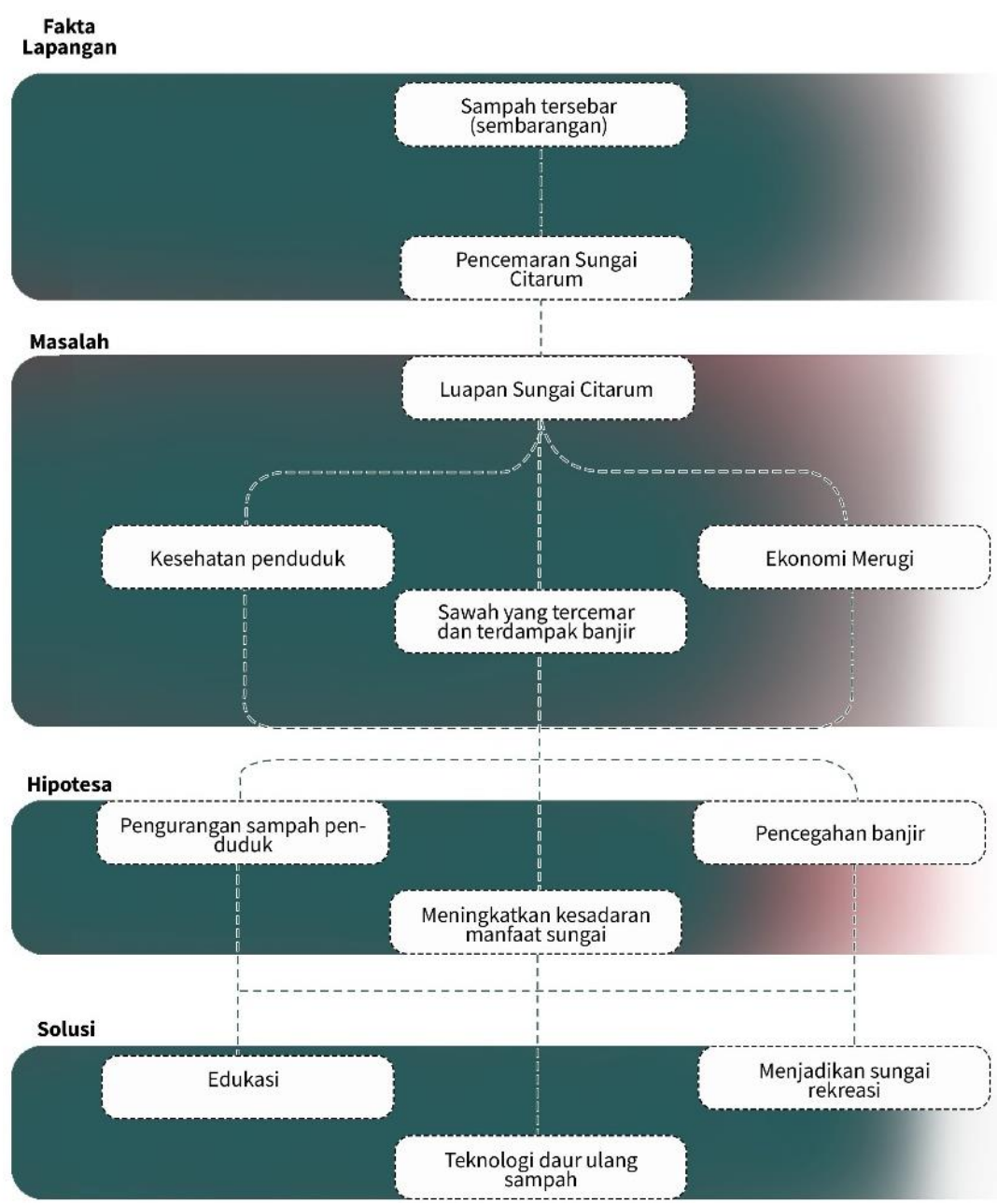

Gambar 3. Skema Permasalahan

Sumber: Penulis, 2021

\section{Perancangan Zonasi Massa}

Untuk mencapai bangunan dengan desain lokalitas yang kuat penggunaan konsep secara konstekstual memberikan pendekatan yang lebih baik. Pada proyek ini pendekatan terhadap desain kontekstual dilakukan berdasarkan hasil analisis tapak dalam menentukan zonasi massa. Analisis yang diangkat antara lain adalah 1). Zonasi Peruntukan Lahan, sebagai analisis singkat untuk mengetahui dan memberikan gambaran akan area yang optimal untuk diisi oleh zonasi program 2). Akses Pejalan Kaki, dalam penentuan akses pedestrian dengan akses terbaik dan terdekat dari segala sisi yakni berada di tengah tapak 3). Area Vegetasi, sebagai bagian dari penyebaran area hijau dan juga menjadi area penyangga bagi kawasan gasifikasi dan juga tempat pengolahan sampah 4). Pintu Masuk Kendaraan Bermotor, yang ditentukan dari pembagian tapak oleh jalan masuk pejalan kaki dan juga berdasarkan fungsi gasifikasi dan pengolahan sampah nantinya 5). Zonasi Program, peletakan fungsi program pada tahap ini masih merupakan zonasi secara umum yang terdiri dari empat program utama yakni fasilitas umum, gasifikasi, pengolahan sampah dan rekreasi 6). Kepadatan Bangunan, dalam menentukan ketinggian bangunan untuk menyamai skyline area Kecamatan Margaasih. 

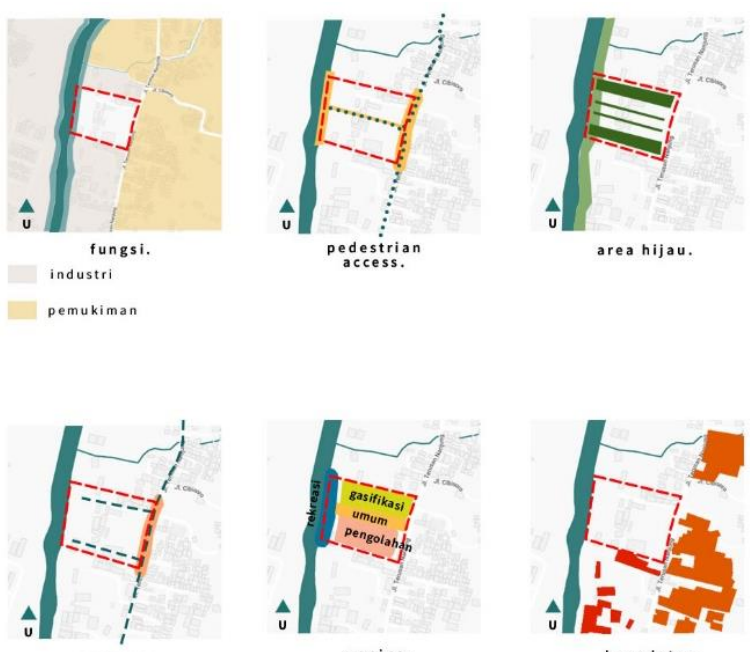

Gambar 4. Analisis Tapak

Sumber: Penulis, 2021

\section{Simulasi Desain Massa}

Dalam menyusun ben
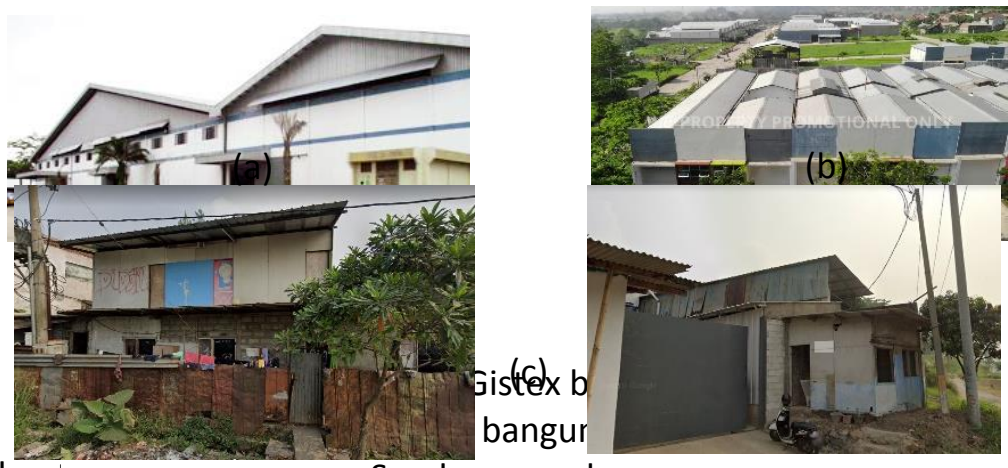

bangunan dengan ciri khas tersendiri tanpa meninggalkan tipologi bangunan Kecamatan Margaasih. Mempelajari secara spesifik bangunan disekitar menjadi kunci penting dalam meraih keselarasan. Yang menjadi perhatian dalam studi tipologi bangunan di kawasan Kabupaten Bandung adalah sebagian besar pabrik yang tidak asing bagi kawasan industri Bandung dan juga bentuk sebagian bangunan-bangunan kecil yang terlihat 'tua'. Meski demikian, bangunanbangunan tersebut menampilkan unsur estetika yang unik seperti halnya pemakaian material asbes sebagai dinding atau pembatas, ada pula pemakaian bahan tipis seperti triplek sehingga bangunan terlihat berbeda dengan bangunan bata biasa seakan-akan tetap terlihat ringan walaupun semua sisi tertutup penuh dan menjadi satu bangunan masif. Guna mendukung tipologi bangunan-bangunan tersebut, selain dengan mengikuti bentuk dan pola seadanya, maka juga dilakukan studi desain lain guna menonjolkan bangunan diantara yang lain yakni, simulasi polapola sampah dalam meniru bentuk, komponen maupun fungsi dari tumpukan-tumpukan sampah. 

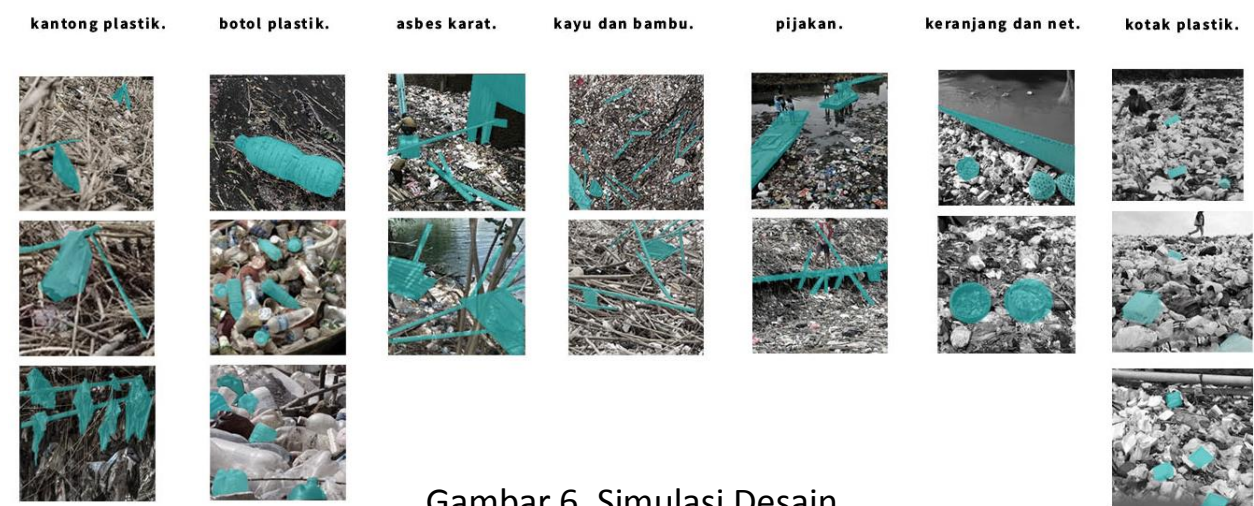

Gambar 6. Simulasi Desain

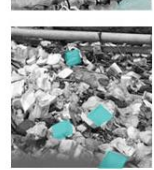

Sumber: Penulis, 2021

\section{Zonasi Detil Program}

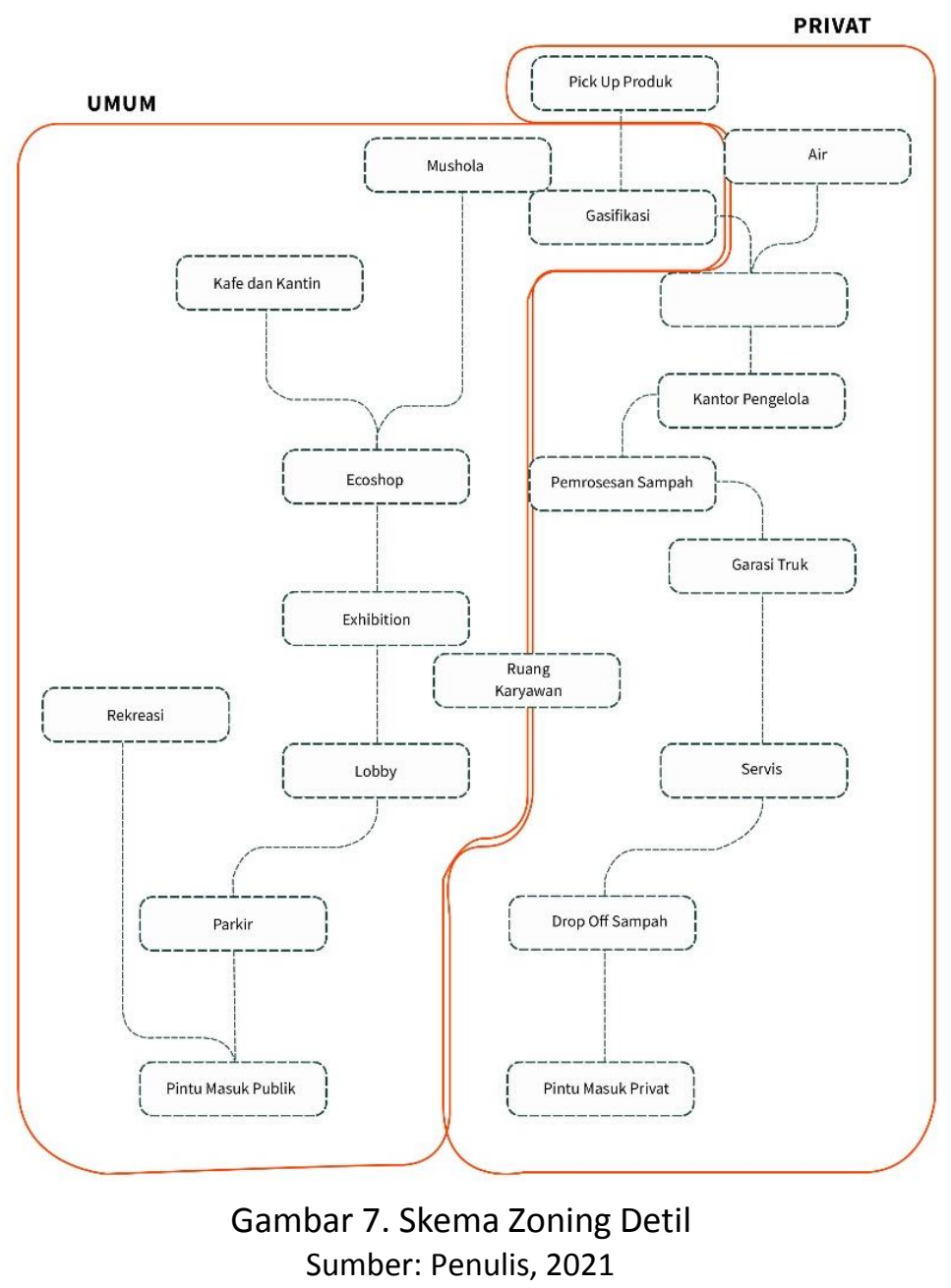

Pada langkah akhir dalam menyusun strategi desain dilakukan zonasi programatik secara detil untuk menentukan alur sirkulasi program secara keseluruhan guna mengetahui letakan ruangruang pendukung dan utama. Pada penyusunan akses masuk tapak proyek telah terbagi menjadi dua jenis alur masuk yang bersifat privat dan publik. Akses masuk bagi program pencacahan dan 
gasifikasi dikategorikan menjadi akses privat karena jalan tersebut hanya diperuntunkan bagi hal yang menjadi kepentingan pengolahan sampah dan servis. Lalu akses yang bersifat publik diperuntunkan bagi pengunjung yang akan mendatangi program rekreasi. Meskipun demikian, diantara dua program pengolahan sampah (gasifikasi dan pencacahan sampah) gasifikasi menjadi program yang paling memungkinkan untuk mewujudkan program edukasi proyek sehingga pada penyusunan zonasi gasifikasi dikelompokan sebagai kelompok publik.

\section{Proses Gubahan Massa}

Tahap terakhir dari proses perancangan konsep massa adalah tujuh tahap transformasi massa. Sebagian besar dari tahap transformasi massa memiliki hubungan terhadap proses perancangan sebelumnya seperti analisis tapak dan zoning detil program, sehingga proses gubahan tersebut dapat dipahami sebagai aplikasi keseluruhan proses perancangan dengan beberapa penyesuaian final dalam mencapai bentukan massa akhir. Tujuh tahap transformasi massa tersebut terdiri atas 1). Elevasi, peningkatan level permukaan tanah tapak sebesar 1 meter dalam merespon permasalahan banjir yang terkadang terjadi di Kabupaten Bandung 2). Koneksi, mencoak tanah di bagian tengah dengan lebar akses sebesar 8 meter sebagai jalur akses pengunjung 3). Massa, peletakan massa pada tapak 4). Pembagian, pemotongan satu massa menjadi tiga massa dengan luasan yang seimbang sebagai wadah program gasifikasi, pencacahan sampah dan juga fasilitas umum 5). Permainan Massa, tidak hanya sebagai pendekatan dalam keberagaman bentuk namun juga penyesuaian terhadap akses pejalan kaki dibawah massa sehingga tetap mendapatkan cahaya matahari 6). Orientasi Bangunan, rekreasi digambarkan menjadi titik pusat tapak sebagai fokus orientasi bangunan dengan tujuan mengarahkan pengunjung menuju titik rekreasi 7). Finalisasi, menerapkan studi simpulasi pola sampah kedalam bentukan massa.

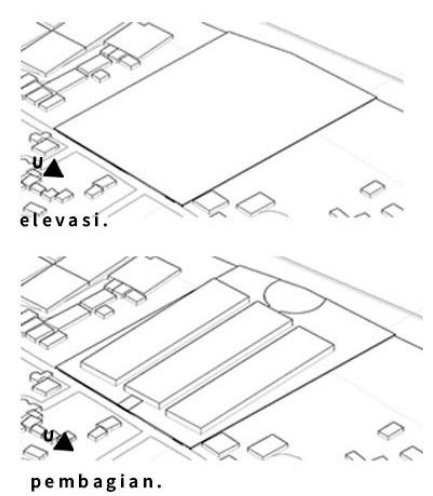

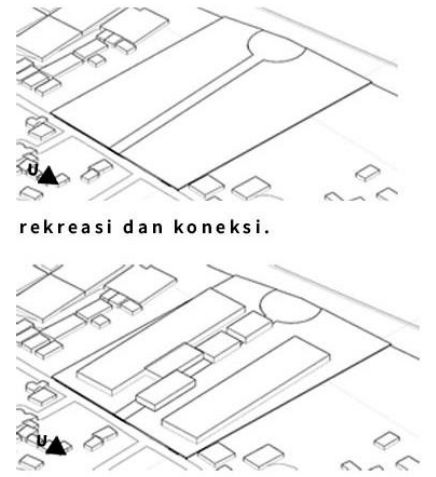

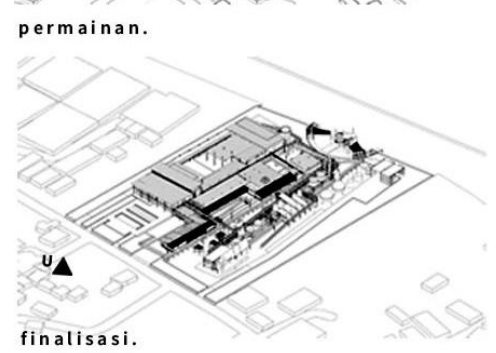

Gambar 8. Proses Gubahan Massa

Sumber: Penulis, 2021

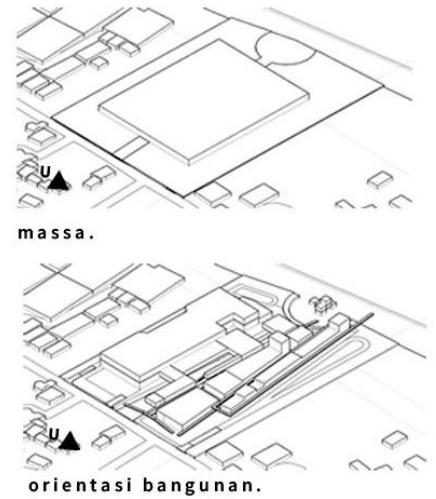

orientasi bangunan. 


\section{Implementasi Desain}

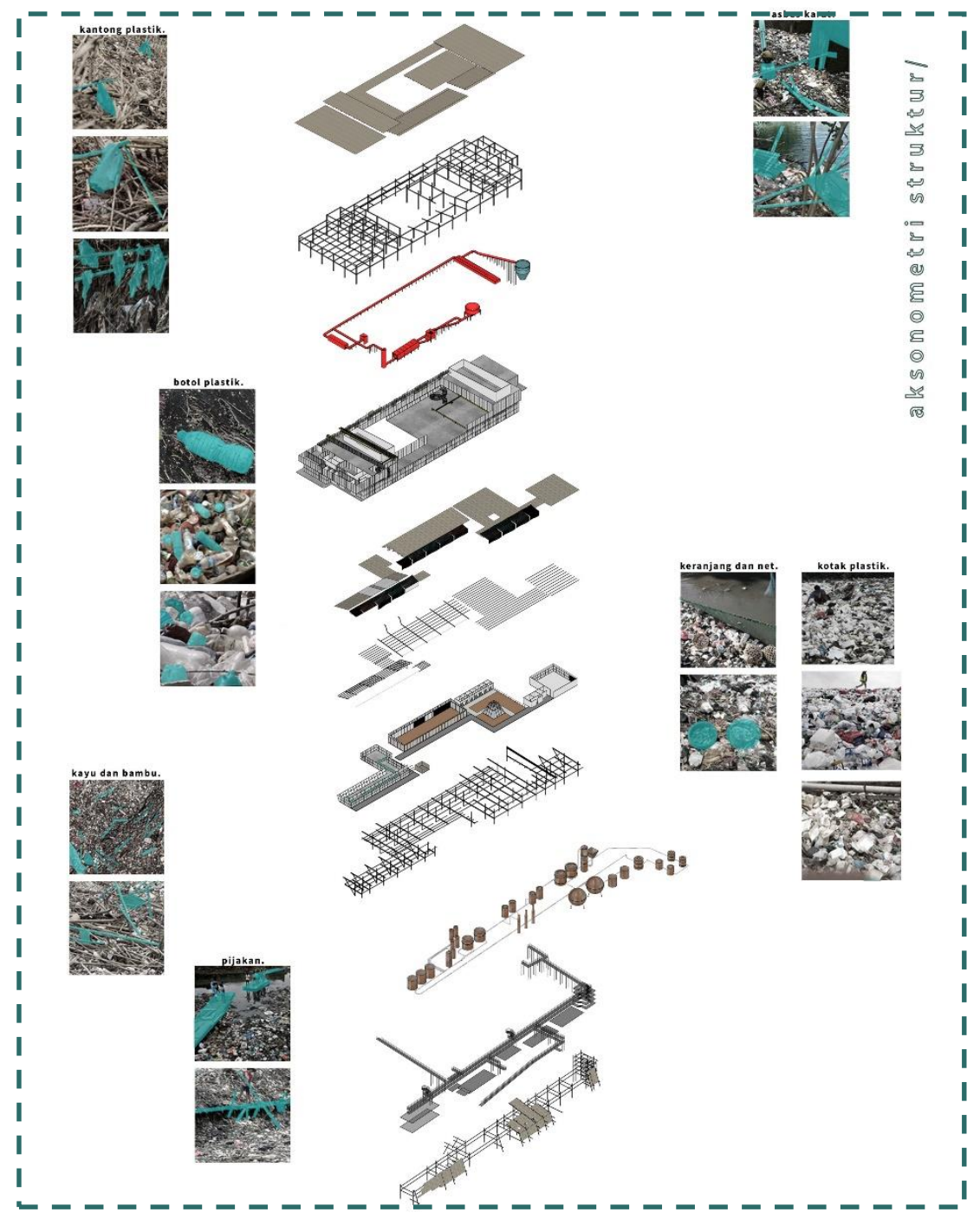

Gambar 9. Aplikasi Desain

Sumber: Penulis, 2021

Teori eco-effectiveness tidak hanya dapat diterapkan secara programatik maupun teknologi, namun juga secara aplikatif pada desain. Selanjutnya dengan mengangkat sampah plastik sebagai bahasa desain diharapkan identitas bangunan dalam spesialiasi sampah dapat terlihat, juga dengan memposisikan massa bangunan sebagaimana adanya tanpa melebih-lebihkan sehingga terlihat melampaui fungsi yang seharusnya, tidak sebagai mall atau tempat riset namun sebagai tempat edukasi rekreasi pengolahan sampah dan juga tidak terlalu membosankan seperti tempat pengolahan pada umumnya dikarenakan adanya kehadiran program bangunan lainnya sebagai rekreasi. Ide yang dihasilkan melalui simulasi-simulasi tersebut bukanlah ide baru. Seperti halnya pemakaian kotak plastik dengan sumber sampah yang merupakan kotak es krim merupakan inspirasi ide dari Microlibrary di Bandung oleh SHAU Bandung pada tahun 2015. Ide tersebut juga menjadi inspirasi fasad keranjang sampah bambu sebagai fasad depan fasilitas umum. Pemakaian keranjang anyaman bambu sebagai fasad bertujuan sebagai ventilasi kecil dan memberikan bayangan yang berbeda melalui cahaya matahari yang masuk. Penggunaan jendela sebagai media yang bersifat transparansi sangat minim yakni pada bagian Ecoshop saja. Sisanya menggunakan Polycarbonate Danpalon menggantikan dinding 
sebagai pemisah antar ruang dalam dan ruang luar. Imajinasikan botol plastik sebagai sebuah wadah, dengan bagian dalam botol berfungsi sebagai ruang yang menaungi aktivitas manusia, sekeliling botol dilapisi oleh dinding dengan transparansi yang berbeda-beda. Cahaya dari luar bisa selalu menerangi aktivitas di dalamnya pada waktu pagi sampai sore dan ketika gelap cahaya di dalam ruangan bisa memberikan estetika tersendiri. Penutup atap dengan rangka baja meniru sampah-sampah asbes bekas. Bahan penutup atap yang dipakai berupa PVC dengan pola motif asbes. Pada sisi bangunan yang berfungsi sebagai jalur orang-orang berlalu lalang ditutup menggunakan terpal. Meimplementasikan studi kantong plastik sebagai penutup ruang. Penggunaan kantong plastik bekas yang didaur ulang lebih tepat dibandingkan dengan menggunakan terpal biasa. Pada bagian rekreasi jaring-jaring bekas walaupun bukan berupa plastik masih dapat memberikan manfaat dengan berfungsi sebagai tempat orang bersantai diatas air dan juga sebagai media bagi orang-orang yang berenang untuk naik ke atas dek.

\section{Perancangan Ruang}

Empat program utama tersusun secara berdampingan, namun masing-masing dengan fungsi yang berbeda juga memiliki pusat aktivitas tersendiri. Dengan demikian sudah pasti ruangan yang terbentuk di dalamnya menyesuaikan langsung dengan fungsi yang akan diwadahinya.

\section{a. Tempat Pencacahan Sampah}

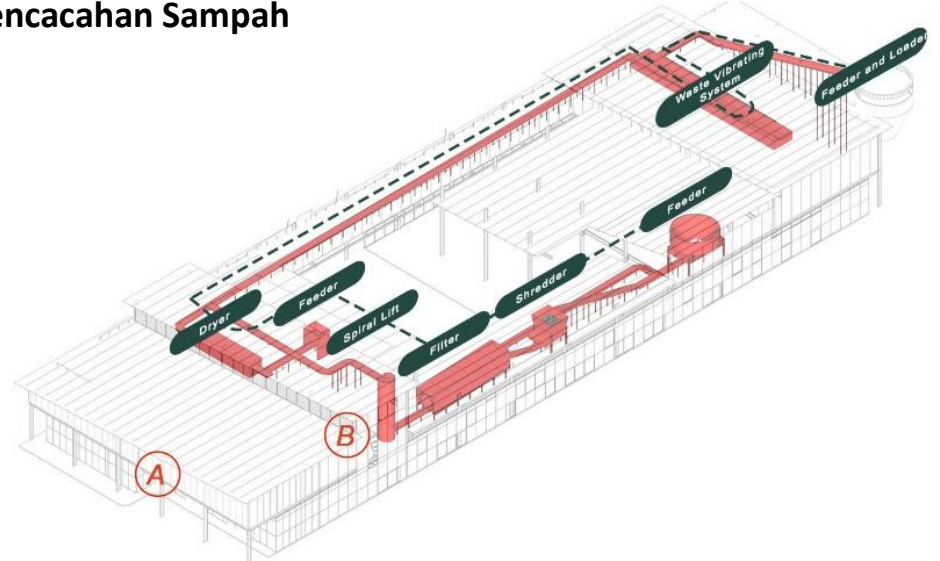

Gambar 10. Susunan Mesin Pencacahan Sampah Sumber: Penulis, 2021

Dengan total luas ruangan sebesar $8.794 \mathrm{~m}^{2}, 5.828 \mathrm{~m}^{2}$ bagian dari massa ini diisi oleh utilitas mesin pencacahan sampah. Tempat pencacahan sampah yang sudah terbangun aslinya hanya terdiri dari satu lantai, namun luasan keseluruhan tapak akan memakan ruang yang lebih besar tentunya. Dengan adanya keterbatasan luas lantai dasar berdasarkan KDB pemerintah setempat maka tempat pencacahan sampah terbagi atas dua level, dimana proses pencacahan dimulai dari drop off sampah pada tempat penampungan awal yang berada di lantai satu bagian tengah bangunan. Sampah-sampah tersebut akan disimpan ataupun ditumpuk di ruang yang telah disediakan. Bagi sampah yang siap diproses akan diangkat menggunakan crane sampah ke dalam mesin feeder yang kemudian dilanjutkan langsung ke tahap pencacahan. Pada lantai dua terdapat tempat penampungan kedua atau terakhir yang juga difasilitasi dengan crane untuk memasukkan sampah ke dalam feeder. Fungsi feeder sendiri yakni menyuplai sampah sesuai porsi yang cukup ke dalam mesin selanjutnya. Transportasi yang dipakai untuk membawa sampah dari lantai satu ke lantai dua adalah spiral lift. Penggunaan mesin tersebut cocok mengingat availibilitas ruangan yang cukup minim. Selanjutnya pada bagian Utara massa pencacahan sampah pada bagian bawah tepat disamping mesin lantai 1 (Gambar 11) Fasad bangunan tidak sepenuhnya tertutup, hal ini bertujuan sebagai ruang view edukasi bagi para pengunjung. 


\section{b. Massa Fasilitas Umum}

Eksibisi biasanya bersifat tidak menetap dan akan terus diisi oleh hal-hal yang berbeda, namun dalam desain bangunan ini interior ruangan diisi dengan sebuah cerita singkat mengenai polusi sampah terlebih sampah plastik. Cerita diawali dengan kesunyian. Sunyi dan damai menjadi gambaran bagi bumi kita dahulu yang masih dipenuhi dengan pohon-pohon. Tiang-tiang putih merupakan implementasi dari pohon-pohon tersebut yang semakin lama semakin pendek dan hilang digantikan oleh tumpukan sampah plastik yang dibuang oleh pengunjung. Lebih jauh lagi pengunjung akan memasuki tahap invasi dimana instalasi lembaran plastik menggantung menutupi jalan seakan-akan perjalanan pengunjung mulai terusik dengan kehadiran plastik dan pada akhirnya akan semakin terganggu dengan kehadiran instalasi jaring-jaring ikan bekas yang membentang menutupi jalan dan menjadi jebakan bagi pengunjung sendiri dan cerita selesai pada pintu keluar. Eksibisi juga diisi dengan storyboard atau papan informasi seputar permasalahan sampah plastik sampai dengan saat ini.

\section{c. Proses Gasifikasi}

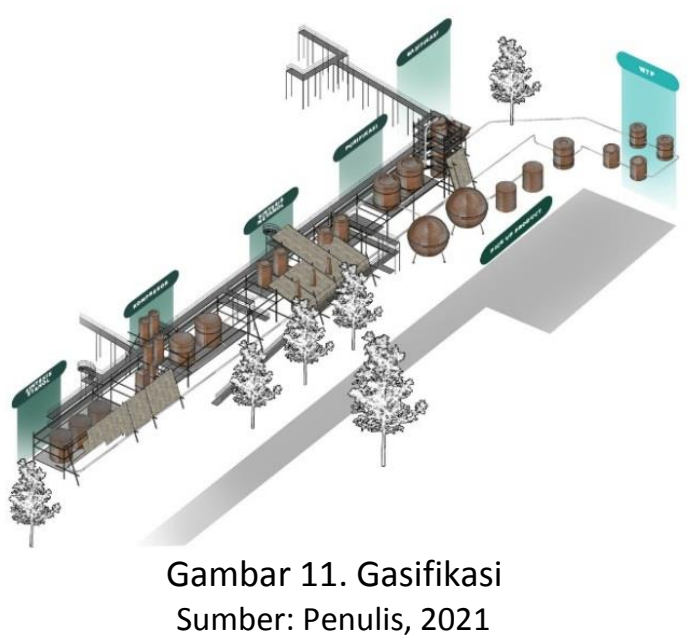

Proses pengolahan sampah menjadi bahan bakar biofuel melalui enam tahapan, yaitu 1). Gasifikasi 2). Purifikasi, proses pembersihan produk dengan air. Pada tahap ini air bekas purifikasi akan mengandung bahan kimia sehingga air perlu melalui tahap pemurnian kembali (koagulasi - flokulasi - sedimentasi filtrasi) 3). Sintesis Metanol 4). Kompresor 5). Sintesis Etanol dan pada akhirnya 6). Pick Up Produk.

\section{d. Rekreasi}

Bertujuan untuk meningkatkan kesadaran masyarakat dengan mendekatkan orang-orang dengan air sungai Citarum, sehingga dengan berbagai aktivitas yang dapat dilakukan di sungai Citarum, orangorang mau mulai menjaga sungai dari pencemaran. Program rekreasi memiliki empat jenis aktivitas, dengan tiga aktivitas diantaranya memiliki interaksi secara langsung dengan sungai 1). Pemancingan, dalam mengembalikan kebiasaan tempo dulu yang sering dilakukan, Lahir Alir Hilir diharapkan dapat menjadikan Sungai Citarum kembali sebagai ekosistem yang utuh 2). Playground, menggunakan konsep tempat bermain yang mencakupi semua umur, difasiltiasi dengan jaring-jaring yang membentang diatas air sehingga orang-orang bisa bersantai langsung diatas air 3). Aktivitas Air, mencakupi berenang dan mendayung kapal botol 4). Cerita Dinding, yang menjelaskan sejarah mengenai sungai Citarum.

\section{KESIMPULAN DAN SARAN}

\section{Kesimpulan}

Proyek pengolahan sampah plastik dengan nama Lahir Alir Hilir dapat dikatakan sebagai salah satu solusi bagi isu sampah plastik di Kecamatan Margaasih. Perancangan alur pengolahan sampah dari awal hingga akhir tersusun secara sistematis. Kehadiran bank sampah dapat mencakupi wilayah dan menjaga sungai dengan baik. Bangunan utama Lahir Alir Hilir sebagai wadah tempat pengolahan 
sampah dipercaya dapat merespon overflowing produksi sampah Kabupaten Bandung. Penerapan barang bekas dan sampah sebagai bagian dari desain bisa dibilang lebih efektif dan efisien dibandingkan dengan membeli produk baru. Rancangan rekreasi sungai juga diyakini dapat melestarikan ekosistem sungai Citarum dari sampah plastik dengan meningkatkan antusias masyrakat terhadap aktifitas sungai.

\section{Saran}

Kesulitan dalam membangun sebuah tempat pengolahan sampah terlebih pabrik gasifikasi adalah perlunya kajian yang sangat mendalam. Hal ini dikarenakan apa yang penulis temukan dan buat masih bisa di optimalkan lebih baik lagi. Bangunan utilitas seperti pabrik gasifikasi memerlukan spesifikasi detil mengenai mesin, jumlah mesin yang diperlukan untuk satu proses, ketentuan pembangunan pipa itu sendiri dan lainnya. Selain itu, pada masa pandemi dengan dibatasinya berpergian juga menjadi kendala, sehingga alangkah lebih baik jika melakukan simulasi desain berdasarkan pola sampah dapat dilakukan secara langsung karena angle pengamatan lebih leluasa tidak terbatas pada satu dua foto saja dan konsep kontekstual akan lebih baik lagi jika kita dapat benar-benar terjun ke lapangan, membuat kuisioner atau wawancara dengan warga sekitar dan merasakan langsung pengalaman aktivitas serta lingkungan area perancangan.

\section{REFERENSI}

Andersen, K. (Producer) 2021. Seaspiracy. Netflix. 89 menit.

Brolin, B. C. (1980). Architecture in Context: Fitting New Buildings with Olds. Van Nostrand Reinhold Company: Inggris.

Gershman, B. \& Bratton, Inc. (2013). Gasification of Non-Recycled Plastics From Municipal Solid Waste In the United States. Diakses 8 Agustus 2021, dari https://plastics.americanchemistry.com/SustainabilityRecycling/Energy-Recovery/Gasification-of-Non-Recycled-Plastics-from-Municipal-Solid-Waste-in-theUnited-States.pdf

Gershman, B. \& Bratton, Inc. (2013). Gasification of Non-Recycled Plastics From Municipal Solid Waste In the United States. Diakses 8 Agustus 2021, dari https://plastics.americanchemistry.com/Education-

Resources/Publications/The-Evolution-of-Mixed-Waste-Processing-Facilities-Technology-and-EquipmentGuide.pdf

Ichzani, M. F. (2018). Waste to Energy, Jatibarang. (Tugas Akhir Sarjana, Universitas Dipenogoro, 2018). Diakses 26 Juni 2021, dari http://eprints.undip.ac.id/70090/

Lyu, Y. (2019). Biomass sources in Parkstad - Research on conditions as a renewable energy. (Master Thesis, Faculty of Architecture \& the Built Environment, Delft University of Technology, 2015). Diakses 6 Agustus 2021, dari https://repository.tudelft.nl/islandora/object/uuid:399229ac-93d7-4255-87cf-5c8d4e2bae26.

Mcdonough, W dan Michael B. (2002). Cradle to Cradle. New York: North Point Press.

Muller, J. A. (2016). The Architecture of Waste - Creating New Avenues for Public Engagement with Trash. (Master of Architecture Thesis, University of Maryland, 2016) Diakses 27 Juni 2021, dari https://drum.lib.umd.edu.

Sundar, S. (2017). Eco-Centre, Mumbai. (Undergraduate Program Thesis, School of Planning and Architecture, New Delhi, 2017). Diakses 26 Juni 2021, dari https://issuu.com/shwetasundar2/docs/report_done

Tam, Kim-Pong. (2020). Gratitude to Nature: Presenting a Theory of its Conceptualization, Measurement, and Effects on Pro-Environmental Behavior. Diakses 27 Juni 2021, dari https://www.researchgate.net/publication/347761651_Gratitude_to_Nature_Presenting_a_Theory_of_i ts_Conceptualization_Measurement_and_Effects_on_Pro-Environmental_Behavior.

Wijayanti, D R dan Sri S. (2015). Waste Bank as Community-based Environmental Governance: A Lesson Learned from Surabaya. Procedia - Social and Behavioral Sciences 184 (2015) $171-179$.

World Bank Technical Guidance Report. (1999). Municipal Solid Waste Incineration. Washington D.C. : The World Bank. 